\title{
BEZPEČNOSŤ INFORMAČNÝCH SYSTÉMOV VEREJNEJ SPRÁVY VO SVETLE ZÁKONA O KYBERNETICKEJ BEZPEČNOSTI A ZÁKONA O INFORMAČNÝCH TECHNOLÓGIÁCH VO VEREJNEJ SPRÁVE ${ }^{1}$
}

\author{
JOZEF ANDRAŠKO ${ }^{2}$
}

\begin{abstract}
ABSTRAKT
Autor sa v predkladanom príspevku venuje otázke bezpečnosti informačných systémov verejnej správy $v$ zmysle novej legislativy, ktorá významným spôsobom pozmenila právnu úpravu bezpečnosti informačných systémov verejnej správy. Autor sa vprvom rade zameral na novoprijatý zákon o informačných technológiách verejnej správy, ktorý upravuje problematiku bezpečnosti informačných technológií verejnej správy. Autor príspevku v druhom rade upriamuje pozornost' na bezpečnost' informačných systémov verejnej správy $v$ zmysle zákona o kybernetickej bezpečnosti, podl'a ktorého sú informačné systémy verejnej správy zaradené medzi základné služby. V závere autor upriami pozornost' na prepojenie a rozdiely votázkach bezpečnosti informačných systémov verejnej správy $v$ zmysle zákona o kybernetickej bezpečnosti a zákona o informačných technológiách vo verejnej správe. Autor skúma danú problematiku z pohl'adu právneho poriadku Slovenskej republiky.
\end{abstract}

Tento príspevok vznikol v rámci projektu APVV-17-0403 Vplyv vzájomného uznávania prostriedkov elektronickej identifikácie na elektronické služby verejnej správy.

2 JUDr. Jozef Andraško, PhD., odborný asistent, Ústav práva informačných technológií a práva duševného vlastníctva, Univerzita Komenského v Bratislave, Právnická fakulta, e-mail: jozef.andrasko@flaw.uniba.sk. 


\section{KLÍČOVÁ SLOVA}

informačné systémy verejnej správy, informačné technológie, kybernetická bezpečnost'

\section{ABSTRACT}

The author deals with the issue of security of public administration information systems in accordance with the new legislation which significantly changed the legal regulation of security of public administration information systems. The author focuses primarily on the newly adopted Information Technologies of Public Administration Act which regulates the issue of security of information technologies of public administration. Secondly, the author focuses on the security of public administration information systems pursuant to the Cyber Security Act in which public administration information systems are considered as the essential services. In conclusion, the author will draw attention to the interconnection and differences in security issues of public administration information systems pursuant to the Cyber Security Act and the Information Technologies in Public Administration Act. The author deals with the issue in question from the perspective of the legal order of the Slovak Republic.

\section{KEYWORDS}

public administration information systems, information technologies, cyber security

\section{1. ÚVOD}

Bezpečnosṫ informačných systémov verejnej správy (d’alej len „ISVS“) zohráva významnú úlohu, a to hned' z niekol'kých dôvodov. Aby verejná správa mohla prostredníctvom svojich orgánov plnit svoje úlohy, musí sa spoliehat na svoje ISVS, resp. na informácie a údaje, ktoré sú v nich spracovávané. Bez dostatočnej úrovne bezpečnosti ISVS by nemohli orgány 
verejnej správy vydávat individuálne správne akty alebo iné finálne formy činnosti verejnej správy. ${ }^{3}$

V kontexte bezpečnosti, resp. informačnej a kybernetickej bezpečnosti je potrebné nahliadat na informačné systémy verenej správy a na informácie, ktoré sa v nich spracúvajú ako na aktíva, ktoré je potrebné chránit. Aby došlo $\mathrm{k}$ zabezpečeniu dostatočnej úrovne ochrany ISVS pred rôznymi hrozbami, je potrebné, aby konkrétne subjekty realizovali bezpečnostné opatrenia, ktoré môžu znižovat dopady bezpečnostných incidentov na tieto systémy. Roztrieštenost právnej úpravy týkajúcej sa povinnosti realizovat bezpečnostné opatrenia môže spôsobit, že subjekty $\mathrm{v}$ rôznych právnych postaveniach nebudú realizovat bezpečnostné opatrenia $\mathrm{v}$ dostatočnej miere resp. ich nebudú realizovat vôbec. $\mathrm{V}$ súvislosti s bezpečnostnými incidentmi je taktiež dôležité, aby príslušné právne predpisy jasne a zrozumitel'ne upravovali, ktorý subjekt je povinný hlásit bezpečnostné incidenty, ktorému subjektu sa takéto bezpečnostné incidenty nahlasujú a $v$ akej lehote.

$\mathrm{V}$ tomto príspevku sa zameriavam na problematiku bezpečnosti ISVS, a to z pohladu právneho poriadku Slovenskej republiky. V prvom rade považujem za potrebné ozrejmit pojmy ako bezpečnost', informačná bezpečnost̉ a kybernetická bezpečnost', a to najmä z teoretického hl'adiska. Následne sa budem venovat problematike bezpečnosti ISVS, a to z pohladu novej právnej úpravy, ktorá sa týka informačných technológií verejnej

\footnotetext{
V súčasnosti zohrávajú ISVS významnú úlohu aj v kontexte cezhraničnej autentifikácie osôb. Konkrétnym príkladom je ISVS, modul IAM (Identity Access Management), taktiež známy ako autentifikačný modul, ktorý plní dôležitú úlohu pri cezhraničnej autentifikácii osôb (občanov iných členských štátov Európskej únie). Pri prvom prihlásení osoby z iného členského štátu Európskej únie do online služby poskytovanou subjektom verejného sektora Slovenskej republiky sa zapíšu z eIDAS uzla do modulu IAM údaje o danej osobe a zároveň sa mu vytvorí elektronická schránka v zmysle zákona č. 305/2013 o elektronickej podobe výkonu pôsobnosti orgánov verejnej moci a o zmene a doplnení niektorých zákonov (zákon o e-Governmente). Bez toho aby sa orgány verejnej správy nemohli spoliehat na pravost', dôveryhodnost' a dostupnost informácií a údajov spracovávaných v ISVS, nemohli by vykonávat svoje úlohy, čo by znemožnilo riadny chod verejnej správy. Bližšie $\mathrm{k}$ problematike cezhraničnej autentifikácie pozri: ANDRAŠKO, J. a MESARČÍK, M. Problematika GDPR v kontexte nariadenia eIDAS. In Digitalizácia, zmeny vonkajšieho prostredia a spoločnost budúcnosti. Bratislava, Univerzita Komenského v Bratislave, Právnická fakulta, s. 8- 22.
} 
správy, ako aj z pohladu právnej úpravy, ktorá sa týka kybernetickej bezpečnosti vo všeobecnosti. Prepojenost' týchto právnych úprav je najviac evidentná, najmä čo sa týka bezpečnosti ISVS. V d’alšej časti príspevku upriamim pozornost’ na povinnost' konkrétnych subjektov v rôznych právnych postaveniach hlásit bezpečnostné incidenty. V tejto súvislosti budem skúmat', aké bezpečnostné incidenty je potrebné hlásit', ktoré subjekty, v akých právnych postaveniach sú povinné hlásit bezpečnostné incidenty, $\mathrm{v}$ akých lehotách a voči ktorým subjektom si musia túto povinnost̉ plnit'. V závere poukážem na najproblematickejšie časti skúmanej problematiky a dovolím si navrhnút aj konkrétne riešenia.

\section{BEZPEČNOSŤ}

Vo všeobecnosti možno povedat', že bezpečnost’ je založená na ochrane aktív pred rôznymi hrozbami pri určitej zranitel'nosti. ${ }^{4}$ Za aktíva možno považovat všetko, čo má pre danú organizáciu ${ }^{5}$ hodnotu. Môže íst? o hmotné aktíva (zariadenie, personál a pod.) alebo o nehmotné aktíva (napr. informácie, údaje, služby, dobré meno, know-how a pod.). Akákol’vek udalost', skutočnost', osoba, sila, ktorá môže spôsobit,, že sa aktíva organizácie dostanú do neželaného stavu (napr. nebudú fungovat’ počítače, zamestnanec ochorie a pod.), sa nazýva hrozba. Najčastejšími hrozbami, ktoré možno aplikovat na aktíva sú prírodné vplyvy (napr. zemetrasenie, búrka a pod.), technické poruchy (napr. výpadok siete, výpadok podpornej infraštruktúry a pod.), chyby v programovom vybavení, neúmyselné l’udské chyby, ciel'avedomá l’udská činnost’ (sabotáž, prieniky hackerov do systému) a pod. ${ }^{6}$

4 VON SOLMS, R., VAN NIEKERK, J. From information security to cyber security. In Computers \& Security, 2013, roč. 38, s. 100.

5 V terminológii informačnej bezpečnosti je pojem organizácia definovaná ako skupina luudí a zariadenie, so zodpovednostou, právomocami a vzájomnými vztahmi. Bližšie pozri bod 2.56 štandardu ISO/IEC 27000:2016 Overview and vocabulary. Pre účely tohto príspevku možno za organizáciu v zmysle informačnej bezpečnosti považovat verejnú správu ako takú, spravujúce subjekty verejnej správy, a teda aj orgány verejnej správy.

${ }^{6}$ OLEJÁR, D. a kol. Manažment informačnej bezpečnosti a základy PKI. Bratislava, 2015, s. 7. [on-line]. Dostupné z: https://www.csirt.gov.sk/bezpecnostna-studovna/mfsr-vzdelavanie89f.html. [citované 28.9.2019]. 
Je potrebné podotknút', že hrozba sa môže, ale nemusí uplatnit. Aby sa hrozba vôbec naplnila, musí aktívum spíňat nejaké predpoklady, ktoré nazývame zranitel’nost'. Každé aktívum je zranitel'né, nakol'ko jeho hodnotu ohrozujú rôzne vplyvy. Pod zranitel'nostou možno chápat chybu, nedostatok $\mathrm{v}$ podobe nedostatočne vyškoleného zamestnanca, ktorý sa svojou neodbornostou a neskúsenostou môže dopúštat chýb. Takýto nedostatok môže byt zneužitý hrozbou v takom rozsahu, že hodnota aktíva môže byt poškodená alebo dokonca zničená. ${ }^{7}$

Aktívum môže byt objektom hrozby ale taktiež môže byt aj cielom útoku. Útok predstavuje úmyselný pokus o naplnenie hrozby, ktorej nositel’om je človek (poškodenie údajov, prienik do systému) a výsledkom je škoda alebo strata aktív. ${ }^{8}$

V prípade, že bude hrozba voči aktívu naplnená a spôsobí narušenie požadovaného stavu aktíva, dochádza k vzniku bezpečnostného incidente. Bezpečnostný incident môže byt̉ spôsobený aktivitou užívatel'a (úmyselne, neúmyselne), alebo iným pôsobením (napr. havária, chyba systému a pod.). Dôsledkom bezpečnostného incidentu je ujma na aktívach organizácie (napr. nefunkčnost’ aktíva, nemožnost’ poskytovania služby, materiálne škody, finančné škody a pod.). Takáto ujma sa nazýva dopad, ktorý sa dá vyjadrit kvantitatívne (napr. finančne ako cena opravy alebo náhrady poškodeného počítača, obnova jeho programového vybavenia a údajov, a pod.) alebo kvalitatívne. ${ }^{9}$

7 POŽÁR, J. Informační bezpečnost. Plzeň: Vydavatelství a nakladatelství Aleš Čeněk, 2005, s. 38.

8 OLEJÁR, D. a kol. Manažment informačnej bezpečnosti a základy PKI. Bratislava, 2015, s. 8. [on-line]. Dostupné z: https://www.csirt.gov.sk/bezpecnostna-studovna/mfsr-vzdelavanie89f.html. [citované 28.9.2019].

9 Pri tažko meratelných dopadoch (napr. pri narušení reputácie) sa využíva kvalitatívne vyjadrenie dopadu bezpečnostného incidentu, a to označením nízky (ak nemá bezpečnostný incident vplyv na chod organizácie), alebo označením vysoký (organizácia nie je spôsobilá vykonávat’ svoje hlavné úlohy). Označenie dopadu bezpečnostného incidentu ako stredný predstavuje situáciu, kedy organizácia už pocítila dôsledky (dokáže plnit svoje primárne úlohy, ale nie v plnom rozsahu). Bližšie pozri OLEJÁR, D. a kol. Manažment informačnej bezpečnosti a základy PKI. Bratislava, 2015, s. 8-9. [on-line]. Dostupné z: https://www.csirt.gov.sk/bezpecnostna-studovna/mfsr-vzdelavanie-89f.html. [citované 28.9.2019]. 
Organizácia počas plnenia svojich úloh čelí mnohým bezpečnostným incidentom či už tým vážnym alebo menej vážnym. Nie všetky hrozby sú pre danú organizáciu opodstatnené, a preto je potrebné vytvorit kritéria, na základe ktorých bude organizácia rozlišovat hrozby na relevantné a tie menej relevantné. Takýmto kritériom je, napr. dopad hrozby, resp. bezpečnostného incidentu, pri ktorom došlo k naplneniu hrozby. Jedno kritérium by nebolo dostačujúce, a preto je potrebné stanovit druhé kritérium, ktorým je pravdepodobnost’ naplnenia hrozby. Tieto oba kritéria sú spojené v riziku. Vo všeobecnosti možno povedat', že riziko predstavuje možnost' (nie nutnost'), že konkrétna hrozba využije zranitel'nost̉ aktíva, čo spôsobí vznik ujmy vlastníkovi aktíva. ${ }^{10}$

Riziká vyplývajúce $\mathrm{z}$ hrozieb voči aktívam organizácie nepredstavujú rovnaký bezpečnostný problém, a preto je potrebné vykonat analýzu rizík, čo predstavuje stanovenie úrovne rizík. Následne sa riziká podl’a závažnosti zoradia a rozhodne sa, ktorými rizikami sa bude organizácia zaoberat’ a ktorými nie. Hranica akceptovatel’ného rizika predstavuje pomyselnú čiaru v zozname rizík. Inými slovami možno povedat, že v prípade rizík, ktoré sa nachádzajú nad čiarou, musí organizácia prijat také riešenia, aby sa hodnoty daného rizika znížili. Takýmto riešením sú opatrenia, ktoré plnia niekol'ko úloh. Na jednej strane znižujú dopady bezpečnostných incidentov na aktíva, a na strane druhej môžu odstraňovat' zranitel'nost' aktív, čím v konečnom dôsledku znižujú pravdepodobnost', že vôbec dôjde k bezpečnostnému incidentu. Takýmto opatrením môže byt', napr. spol’ahlivá identifikácia a autentifikácia, šifrovanie citlivej informácie, zálohovanie údajov a pod. ${ }^{11}$

V dobe kedy sa informácie prenášajú a spracúvajú elektronicky a digitálne prostredníctvom informačných a komunikačných technológií (d’alej len „IKT“) sa problematika bezpečnosti spája najmä s pojmami informačná bezpečnost’ a kybernetická bezpečnost'. V odbornej literatúre sa pojem informačná bezpečnosť častokrát zamieňa za pojem kybernetická

10 OLEJÁR, D. a kol. Manažment informačnej bezpečnosti a základy PKI. Bratislava, 2015, s. 9. [on-line]. Dostupné z: https://www.csirt.gov.sk/bezpecnostna-studovna/mfsr-vzdelavanie89f.html. [citované 28.9.2019].

11 Tamtiež, s. 9-10. 
bezpečnosṫ a naopak. Nejasnost $\mathrm{v}$ terminológii spomínaných pojmov vychádza najmä zo skutočnosti, že predmetné pojmy sú upravené v mnohých dokumentoch, národného, ako aj medzinárodného charakteru, avšak tieto dokumenty nemajú právnu záväznosté. Nejednotnosţ týchto pojmov, ktoré sú používané najmä v rôznych stratégiách, ktoré upravujú bezpečnost $\mathrm{v}$ kybernetickom priestore spôsobila roztrieštenost pohladov na skúmané pojmy.

Pojmy informačná a kybernetická bezpečnost̉ budem analyzovat najmä prostredníctvom medzinárodných štandardov, ktoré túto problematiku riešia už viac než 20 rokov. Hoci štandardy nie sú právne záväzné, častokrát sa na ne legislatíva odvoláva a dávajú presnejšie formulované odpovede na otázky, ktoré súvisia informačnou a kybernetickou bezpečnostou.

Štandard možno z formálneho hladiska definovat ako: „dokument, ktorý vznikol na základe konsenzu a bol schválený uznaným orgánom, ktorý poskytuje pre všeobecné a opakované použitie pravidlá, smernice alebo charakteristiky činností alebo ich výsledkov zamerané na dosiahnutie optimálneho stupňa usporiadania $v$ danom kontexte. “12

Z hladiska orgánu, ktorý prijíma konkrétny štandard, možno štandardy rozdelit na formálne a neformálne. Zatial’ čo formálne štandardy boli schválené národnými ${ }^{13}$, európskymi ${ }^{14}$ alebo medzinárodnými štandardizačnými orgánmi ${ }^{15}$, neformálne štandardy boli publikované organizáciami pre rozvoj štandardov, ktoré však nie sú uznané za štandardizačné orgány. ${ }^{16}$

12 ISO/IEC Guide 2:2004 Standardization and related activities - General vocabulary, s. 10.

${ }^{13}$ Z oznam národných štandardizačných orgánov dostupný z: https://standards.cen.eu/dyn/www/f?p = CENWEB:5. [citované 28.9.2019].

${ }^{14}$ Medzi európske štandardizačné orgány možno zaradit European Committee for Standardization (CEN), European Committee for Electrotechnical Standardization (CENEL) a European Telecommunications Standards Institute (ETSI).

15 Medzi medzinárodné štandardizačné orgány možno zaradit International Organization for Standardization (ISO), International Electrotechnical Commission (IEC) a International Telegraph Union (ITU).

${ }^{16}$ Napr. American Society for Testing Materials International, Society of Automotive Engineers, Internet Engineering Task Force a i. 
Problematike informačnej bezpečnosti sa venuje viacero medzinárodných štandardov. $\mathrm{V}$ d’alších častiach analýzy sa zameriam na medzinárodné ISO štandardy, ako aj na diela autorov, ktorí sú považovaní za odborníkov v oblasti informačnej a kybernetickej bezpečnosti.

\subsection{INFORMAČNÁ BEZPEČNOSŤ - POJEM}

Medzinárodný štandard ISO/IEC 27000:2016 Information technology -Security techniques -- Information security management systems -Overview and vocabulary (d'alej len „ISO/IEC 27000:2016“) definuje informačnú bezpečnost̉ ako zachovanie dôvernosti, integrity a dostupnosti informácií.

Dôvernost', integrita a dostupnost̉ predstavujú základné bezpečnostné požiadavky na ochranu informácií. Bezpečnostná požiadavka na zaistenie dôvernosti informácie znamená, že informácia je chránená pred prezradením neoprávneným osobám. Príkladom informácií, ktoré si vyžadujú ochranu pred neoprávneným prístupom sú, napr. osobné údaje, informácie týkajúce sa bezpečnosti štátu a pod. ${ }^{17}$

Bezpečnostná požiadavka na zaistenie integrity údajov znamená, že údaje ${ }^{18}$ sú chránené pred náhodnou alebo úmyselnou modifikáciou, ktorá by mohla mat vplyv na platnoste údajov. Príkladom by mohla byt̉ ochrana údajov $\mathrm{v}$ rámci transakcií, kde dochádza $\mathrm{k}$ platbe, kde by mohlo dôjst k modifikácii sumy. ${ }^{19}$

17 TODOROV, D. Mechanics of Users Identification and Authentication. Fundamentals of Identity Management. USA: Auerbach Publications, 2007, s. 2.

${ }^{18} \mathrm{~V}$ tomto prípade je potrebné rozlišovat medzi informáciou a údajom. Ako uvádza Olejár, informácie sú obsahom údajov a údaje sú len forma zápisu informácí. To znamená, že tú istú informáciu (napr. desat') možno zapísat v rôznej forme (napr. X, ten a pod.). Bližšie pozri OLEJÁR, D. a kol.: Manažment informačnej bezpečnosti a základy PKI. Bratislava, 2015, s. 11. [on-line]. Dostupné z: https://www.csirt.gov.sk/bezpecnostna-studovna/mfsrvzdelavanie-89f.html. [citované 28.9.2019]. K rozdielu medzi pojmom údaj a informácia taktiež pozri: POLČÁK, R. Informace a data v právu. In Revue pro právo a technologie 7, 2016, s. 67-91.

OLEJÁR, D. a kol.: Manažment informačnej bezpečnosti a základy PKI. Bratislava, 2015, s. 910.[on-line]. Dostupné z: https://www.csirt.gov.sk/bezpecnostna-studovna/mfsrvzdelavanie-89f.html. [citované 28.9.2019].

19 TODOROV, D. Mechanics of Users Identification and Authentication. Fundamentals of Identity Management. USA: Auerbach Publications, 2007, s. 2. 
Dostupnost’ informácie ako bezpečnostná požiadavka znamená, že informácie a služby, ktoré poskytujú osobám a organizáciám, musia byt dostupné používatel'ovi kedykol'vek, ked’ o to požiada. Napr. webová stránka, prostredníctvom ktorej sa osoby identifikujú a autentifikujú pre využívanie elektronických služieb verejnej správy, musí byt dostupná kedykol'vek, ak o to daná osoba požiada. Nedostupnost́ webovej stránky by narušila poskytovanie služieb. ${ }^{20}$

Popri vyššie uvedených bezpečnostných požiadavkách na ochranu informácií, existujú aj iné bezpečnostné požiadavky ako autentickost', súkromnost', anonymita, pseudonymita, nepopretie pôvodu, nepopretie doručenia, resp. $v$ prípade ochrany systémov poznáme dosledovatel'nost. ${ }^{21}$

V zmysle predmetného štandardu sa za informácie považujú nielen informácie v digitálnej forme (údaje uložené na elektronických alebo optických médiách), ale aj v materiálnej forme (napr. papier). Medzi informácie môžeme taktiež zaradit informácie ako vedomosti zamestnanca. Informácie môžu byt prenášané rôznymi spôsobmi, kuriérom, elektronickou alebo verbálnou komunikáciou. Bez ohl’adu na formu informácií a spôsob jej prenosu platí, že si vyžadujú dostatočnú ochranu. ${ }^{22}$

Whitman a Mattord definujú informačnú bezpečnost’ ako: „ochranu informácií a ich klúčových prvkov, vrátane systémov a hardvéru, ktoré použivajú, uchovávajú a prenášajú túto informácie. “23 Kl'účovými prvkami sú $\mathrm{v}$ tomto prípade dôvernost', integrita a dostupnost informácie. ${ }^{24}$

Podla Olejára sa pojem informačná bezpečnost̉ používa minimálne v troch významoch: ${ }^{25}$

20 Tamtiež, s. 2.

21 Pre tieto bezpečnostné požiadavky bližšie pozri OLEJÁR, D. a kol.: Informačná bezpečnosṫ. Bratislava, 2013. s. 12. [on-line]. Dostupné z: https://www.csirt.gov.sk/bezpecnostnastudovna/mfsr-vzdelavanie-89f.html. [citované 28.9.2019].

22 ISO/IEC 27000:2016, s. 15.

23 WHITMAN, M.E. a MATTORD, H.J. Principles of Information security. Boston: Course Technology, 2012, s. 9.

24 Dôvernost', integrita a dostupnost’ informácie sú v odbornej literatúre označené ako CIA trojuholník. Skratka CIA vychádza zo začiatočných písmen anglických názvov týchto základných bezpečnostných požiadaviek (Confidentiality, Integrity, Availability). 
- je to ideálny stav systému alebo organizácie, ktorý sa dá charakterizovat tak, že všetko (IKT) funguje v súlade s požiadavkami (stanovenými napr. v bezpečnostnej politike) a v systéme/organizácii nedochádza $\mathrm{k}$ bezpečnostným incidentom,

- označuje činnost̉ smerujúcu k dosiahnutiu ideálneho stavu,

- medziodborová oblast', ktorá skúma hrozby voči IKT a informácii a metódy eliminácie rizík, ktoré z nich vyplývajú.

\subsection{KYBERNETICKÁ BEZPEČNOSŤ - POJEM}

Pojem kybernetická bezpečnost̉ je v zmysle medzinárodného štandardu ISO/IEC 27032:2012 Information technology -- Security techniques -Guidelines for cybersecurity (d’alej len „ISO/IEC 27032:2012“) definovaný ako zachovanie dôvernosti, integrity a dostupnosti informácií ${ }^{26}$ $\mathrm{v}$ kybernetickom priestore. ${ }^{27} \mathrm{~V}$ porovnaní $\mathrm{s}$ informačnou bezpečnostou, pôjde teda len o informácie, ktoré sú prenášané a uložené v kybernetickom priestore. Kybernetická bezpečnost' sa vztahuje na opatrenia, ktoré by zainteresované strany ${ }^{28}$ mali stanovit pre vytvorenie a zachovanie bezpečnosti v kybernetickom priestore. ${ }^{29}$

V zmysle vyššie uvedenej definície by sme mohli povedat, že kybernetická bezpečnost̉ je informačná bezpečnost kybernetického

25 OLEJÁR, D. a kol. Manažment informačnej bezpečnosti a základy PKI. Bratislava, 2015. s. 16. [on-line]. Dostupné z: https://www.csirt.gov.sk/bezpecnostna-studovna/mfsr-vzdelavanie89f.html. [citované 28.9.2019].

${ }^{26}$ Podla niektorých autorov je kybernetická bezpečnost̉ postavená na princípoch, ktoré sa nazývajú triády kybernetickej bezpečnosi. Konkrétne ide o:

1. CIA (Confidentiality, Integrity, Availability)

2. Prvky kybernetickej bezpečnosti (Ludia, Technológie, Procesy)

3. Životný cyklus kybernetickej bezpečnosti (Prevencia, Detekcia, Reakcia). Bližšie pozri KOLOUCH, J., BAŠTA, P. a kol. CyberSecurity. Praha: CZ.NIC, z.s.p.o, 2019. s. 45-68 alebo BAYUK, L. a kol.: Cyber security policy guidebook. Wiley, 2012, s. 2-3.

27 Predmetný medzinárodný štandard odkazuje na viacerých miestach na ISO štandardy, ktoré sa aplikujú v prípade informačnej bezpečnosti.

${ }^{28}$ Medzi zainteresované strany v kybernetickom priestore možno zaradit užívatelov (jednotlivci, súkromné a verejné organizácie) a poskytovatel’ov (poskytovatelia Internetu a poskytovatelia aplikačných služieb).

${ }^{29}$ ISO/IEC 27032:2012, s. 17. 
priestoru. Je viac ako potrebné ozrejmit pojem kybernetický priestor (cyberspace), nakolko tento pojem určuje obsah pojmu kybernetická bezpečnost'.

Neexistuje jednoznačná, všeobecne akceptovaná definícia pojmu kybernetický priestor. Kybernetický priestor možno chápat ako systém systémov (SoS) zložený z rôznych digitálnych zariadení spojených počítačovými sietami, pripojenými na Internet (vrátane programového vybavenia, údajov, aplikačných programov, technickej infraštruktúry) a l’udí, ktorí v tomto priestore pôsobia, činností, ktoré v ňom prebiehajú, pravidiel, ktoré upravujú činnosti a vztahy v priestore. Iné definície chápu kybernetický priestor ako virtuálny systém informácií, vztahov, činností, ktoré vznikajú pri spracovaní informácií prostredníctvom digitálnych IKT, ktorý však neexistuje $\mathrm{v}$ materiálnej forme. ${ }^{30}$

V zmysle medzinárodného štandardu ISO/IEC 27032:2012 predstavuje kybernetický priestor komplexné prostredie, ktoré vzniklo interakciou l’udí, softvéru a služieb na Internete prostredníctvom zariadení a sietí, technológií k nemu pripojených, ktoré neexistuje $\mathrm{v}$ žiadnej fyzickej podobe. $^{31}$

Autori odbornej literatúry chápu kybernetický priestor ako geograficky neobmedzený, nefyzický priestor, v ktorom sa nezávisle od času, dial'ky a miesta vykonávajú transakcie medzi lud’mi, medzi počítačmi a medzi počítačmi a l’ud'mi. Charakteristickým znakom kybernetického priestoru je nemožnost̉ určit presné miesto a čas, kedy došlo k danej aktivite alebo kde došlo k presunu informáciii. ${ }^{32}$

Hoci ISO/IEC 27032:2012 a niektorí autori odbornej literatúry chápu kybernetický priestor ako prostredie, ktoré neexistuje vo fyzickej podobe, nemožno ho chápat izolovane od jeho technologických komponentov, z ktorých je tvorený. Avšak, okrem technologickej úrovne má kybernetický

30 Bližšie pozri: ANDRAŠKO, J. a kol.: Zákon o kybernetickej bezpečnosti. Komentár. Bratislava: Wolters Kluwer SR s.r.o. 2018, s. 96.

31 ISO/IEC 27032:2012, s. 12.

32 HAMELINK, C. J. The ethics of cyberspace. Sage, 2001, s. 9. 
priestor aj sociálno-technickú úroveň, v rámci ktorej sa vykonávajú rôzne kybernetické aktivity. ${ }^{33}$

Legálnu definíciu pojmu kybernetický priestor možno nájst̉ v zákone č. 69/2018 Z. z. o kybernetickej bezpečnosti a o zmene a doplnení niektorých zákonov (d’alej len „zákon o KB“). Kybernetický priestor je v zmysle § 3 písm. b) predmetného zákona definovaný ako: „globálny dynamický otvorený systém sietí a informačných systémov, ktorý tvoria aktivované prvky kybernetického priestoru, osoby vykonávajúce aktivity $v$ tomto systéme a vztahy a interakcie medzi nimi. “ Predmetná definícia má viacero nedostatkov, nakol'ko medzi prvky, ktoré patria do kybernetického priestoru zaradzuje len aktivované prvky, čím vylučuje prvky, ktoré nie sú aktivované. Ako príklad neaktivovaných prvkov možno uviest’ siete, počítače a zariadenia, ktoré sa nemusia dočasne používat', avšak stále sú súčastou technologickej infraštruktúry, ktorú je potrebné chránit’. V prípade ak by sme pripustili, že kybernetická bezpečnost’ sa vztahuje len na aktívne prvky kybernetického priestoru, potom by pasívne komponenty prestali byt prvkami kybernetického priestoru. Takéto úvahy sú namieste najmä z dôvodu, že nová právna úprava týkajúca sa ochrany informačných technológií verejnej správy sa netýka len ISVS, ale aj infraštruktúry, ktorá zabezpečujúce implementáciu a prevádzkovanie ISVS. ${ }^{34}$

Pre úplnosṫ je potrebné dodat', že kybernetická bezpečnost’ sa v zmysle štandardu ISO/IEC 27032:2012 opiera o informačnú bezpečnost’ (information security), bezpečnost’ aplikácií (application security), bezpečnost’ siete (network security) a bezpečnost' Internetu (Internet security) ako o základné stavebné kamene. Kybernetická bezpečnoste je jednou z činností potrebných pre ochranu kritickej informačnej infraštruktúry (critical information infrastructure protection). Primeraná ochrana služieb kritickej infraštruktúry súčasne prispieva k základným potrebám bezpečnosti

33 VAN DEN BERG, J. a kol. On (the Emergence of) Cyber Security Science and its Challenges for CyberSecurity Education. NATO STO/IST-122 symposium, Tallinn, 13-14 október 2014, s. $12-2$.

34 Problematickým aspektom pojmu kybernetický priestor v zmysle zákona o KB je aj zaradenie l’udí medzi prvky kybernetického priestoru. Bližšie pozri ANDRAŠKO, J. a kol.: Zákon o kybernetickej bezpečnosti. Komentár. Bratislava: Wolters Kluwer SR s.r.o. 2018, s. 95. 
(bezpečnost', spolahlivost̉ a dostupnost kritickej infraštruktúry) za účelom dosiahnutia cielov kybernetickej bezpečnosti. ${ }^{35}$

V odbornej literatúre možno nájst̉ rôzne definície pojmu kybernetická bezpečnost. ${ }^{36}$ Kolouch chápe kybernetickú bezpečnost $\mathrm{v}$ dvoch rovinách. V prvej rovine definuje kybernetickú bezpečnost̉ ako: „súhrn právnych, organizačných, technických a vzdelávacích prostriedkov, ktoré smerujú $k$ zaisteniu ochrany počítačových systémov a d'alšı̌ch prvkov IKT, aplikáciú, údajov a uživatelov. “37

V druhej rovine chápe kybernetickú bezpečnost ako: „schopnost' počítačových systémov a využívaných služieb reagovat’ na kybernetické hrozby či útoky a ich následky, ako aj plánovanie obnovy funkčnosti počítačových systémov a služieb s nimi spojených.“

Pojem kybernetická bezpečnost̉ je definovaný zákone o KB. V zmysle § 3 písm. g) zákona o KB je kybernetická bezpečnost ${ }^{38}$ definovaná ako: „stav, $v$ ktorom sú siete a informačné systémy schopné odolávat na určitom stupni spol'ahlivosti akémukol'vek konaniu, ktoré ohrozuje dostupnost', pravost', integritu alebo dôvernost' uchovávaných, prenášaných alebo spracúvaných údajov alebo súvisiacich služieb poskytovaných alebo prístupných prostredníctvom týchto sietí a informačných systémov. "Predmetná definícia vychádza z pojmu bezpečnost̉ sietí a informačných systémov v zmysle čl. 4 ods. 2 smernice Európskeho parlamentu a Rady (EÚ) 2016/1148 zo 6. júla 2016 o opatreniach na zabezpečenie vysokej spoločnej úrovne bezpečnosti sietí a informačných systémov v Únii (d’alej len „smernica NIS“). ${ }^{39}$

35 ISO/IEC 27032:2012, s. 17.

${ }^{36}$ K pojmu kybernetická bezpečnost pozri: POLČÁK, R: Kybernetická bezpečnost. In Právo informačních technológií. Praha: Wolters Kluwer ČR, 2018, s. 587-593 alebo POLČÁK, R. Kybernetická bezpečnost jako aktuální fenomén českého práva. In Revue pro právo a technologie, 2015, č. 11, s. 95. [o n-1ine]. Dostupné z: https://journals.muni.cz/revue/article/view/2980. [citované 29.9.2019].

37 KOLOUCH, J., BAŠTA, P. a kol. CyberSecurity. Praha: CZ.NIC, z.s.p.o, 2019. s. 45-68 alebo BAYUK, L. a kol.: Cyber security policy guidebook. Wiley, 2012, s. 45.

38 Bližšie k pojmu kybernetická bezpečnost̉ v zmysle zákona o KB pozri ANDRAŠKO, J. a kol. Zákon o kybernetickej bezpečnosti. Komentár. Bratislava: Wolters Kluwer SR s.r.o. 2018, s. 100-103. 


\subsection{ROZDIEL MEDZI INFORMAČNOU A KYBERNETICKOU BEZPEČNOSŤOU}

$\mathrm{V}$ prvom rade si je potrebné uvedomit, že $\mathrm{v}$ prípade skúmaných pojmov nejde o synonymá. Informačnú a kybernetickú bezpečnost̉ nemožno v zmysle skúmaných štandardov vnímat ako totožné pojmy a nie je ani vhodné ich rozlišovat na základe toho, ktorý pojem je širší alebo užší.

$\mathrm{V}$ prípade kybernetickej bezpečnosti je okrem iného taktiež cielom ochrana informácií, ale len tých z prostredia kybernetického priestoru. V tejto súvislosti si je potrebné uvedomit, že z pohl’adu ochrany informácie ako aktíva, sú $\mathrm{v}$ prípade informačnej bezpečnosti chránené nie len informácie v elektronickej podobe, ale aj vo fyzickej podobe.

V druhom rade je potrebné podotknút, že kybernetická bezpečnost̉ má z pohladu štandardov za ciel’ zabezpečit zdielanie a koordináciu medzi jednotlivými bezpečnostnými doménami. Možno povedat, že kybernetická bezpečnost̉ spravuje bezpečnostné problémy, ktoré nerieši žiadna z bezpečnostných domén alebo môže byt identifikovaná viacerými doménami. $\mathrm{V}$ druhom prípade je potrebné zdielat a koordinovat informácií pre efektívne a komplexné riešenie bezpečnostného problému. ${ }^{40}$

Avšak v súčasnosti sa v právnom poriadku Slovenskej republiky nerozlišuje medzi informačnou bezpečnostou a kybernetickou bezpečnostou. Z právneho hladiska, ako aj praktického hladiska je rozlišovanie medzi informačnou bezpečnostou a kybernetickou bezpečnostou nepodstatné. Dôležitejšie je, aby právna úprava zabezpečila dostatočnú ochranu informačných systémov a informácií, ktoré sa v nich

${ }^{39}$ V zmysle smernice NIS sa bezpečnost sietí a informačných systémov chápe ako: „schopnost’ sietí a informačných systémov odolávat' na určitom stupni spol'ahlivosti akémukolvek konaniu, ktoré ohrozuje dostupnost', pravost', integritu alebo dôvernost' uchovávaných, prenášaných alebo spracúvaných údajov alebo súvisiacich služieb poskytovaných alebo prístupných prostredníctvom týchto sietí a informačných systémov. "Smernica NIS chápe bezpečnost sietí a informačných systémov ako vlastnost’ sietí a informačných systémov, zatial čo v zákone o KB je chápaná kybernetická bezpečnost ako stav.

${ }^{40}$ V niektorých prípadoch je pojem kybernetickej bezpečností spájaný s ochranou kritickej informačnej infraštruktúry, čo však nie je pravdou. Súvislosṫ medzi kybernetickou bezpečnostou a ochranou kritickej informačnej infraštruktúry je častokrát viac ako zrejmá, nakolko napr. infraštruktúra telekomunikačných sietí zabezpečuje prístup do kybernetického priestoru. 
spracúvajú, tak aby sa dalo spol’ahnút na ich dôvernost', dostupnosţ a integritu. Taktiež je potrebné, aby sa zabezpečila nielen ochrana informácií v materiálnej podobe, ale aj informácií, ktoré sú spracúvané $\mathrm{v}$ elektronickej alebo digitálnej forme.

\section{BEZPEČNOSŤ ISVS V PRÁVNOM PORIADKU SLOVENSKEJ REPUBLIKY}

Právna úprava ISVS a otázka ich bezpečnosti prešla v poslednom období výraznými zmenami. V prvom rade, zákon č. 275/2006 Z. z. o informačných systémoch verejnej správy a o zmene a doplnení niektorých zákonov (d’alej len „zákon o ISVS“) bol zrušený zákonom č. 95/2019 Z. z. o informačných technológiách vo verejnej správe a o zmene a doplnení niektorých zákonov (d’alej len „zákon o ITVS“), ktorý nadobudol účinnos? 5. mája 2019.

Problematika bezpečnosti ISVS je v súčasnosti stále upravená vo výnose Ministerstva financií Slovenskej republiky č. 55/2014 Z. z. o štandardoch pre informačné systémy verejnej správy. Predmetný výnos obsahuje bezpečnostné štandardy. ${ }^{41}$

Bezpečnosṫ ISVS je taktiež predmetom zákona o KB, nakolko za určitých okolností môže byt konkrétny ISVS zaradený medzi základné služby a jeho správca do registra prevádzkovatel’ov základných služieb (d’alej len „PZS“). V takejto situácii je správca $\mathrm{v}$ pôsobnosti ktorého je konkrétny ISVS povinný plnit povinnosti v zmysle zákona o KB.

V nasledujúcej časti príspevku dôjde k ozrejmeniu pojmu informačná technológia verejnej správy, ktorý v sebe zahŕňa aj pojem informačný systém verejnej správy. Taktiež upriamim pozornost̉ na ustanovenia zákona o ITVS, ktoré upravujú problematiku bezpečnosti informačných technológií verejnej správy. Následne poukážem na zákon o KB a jeho vztah $\mathrm{k}$ zákonu o ITVS, a to najmä z pohladu bezpečnostných opatrení resp. iných

41 Výnos Ministerstva financií Slovenskej republiky č. 55/2014 Z. z. o štandardoch pre informačné systémy verejnej správy v znení neskorších predpisov zostáva platný a účinný do nadobudnutia účinnosti vykonávacieho právneho predpisu podl’a $\S 31$ zákona o ITVS, najneskôr však do 1. mája 2020. 
povinností, ktoré musia konkrétne subjekty plnit, aby zabezpečili dostatočnú úroveň bezpečnosti informačných technológií verejnej správy, resp. ISVS.

\subsection{BEZPEČNOSŤ ISVS V ZÁKONE O ITVS}

Zákon o ITVS v porovnaní so zrušeným zákonom o ISVS definuje pojem informačné technológie verejnej správy (d’alej len „ITVS“) a rozširuje svoju pôsobnost’ aj na bezpečnost’ týchto technológií. V zmysle $\S 2$ ods. 2 zákona ITVS sú ITVS definované ako: „informačná technológia v pôsobnosti správcu podporujúca služby verejnej správy, služby vo verejnom záujme alebo verejné služby." Informačné technológie sú v zmysle § 2 ods. 1 zákona o ITVS chápané ako: „prostriedok alebo postup, ktorý slúži na spracúvanie údajov alebo informácií $v$ elektronickej podobe.“ Zákon o ITVS uvádza príklady informačných technológií, konkrétne informačný systém, infraštruktúru, informačnú činnost' a elektronické služby. Definícia pojmu informačný systém verejnej správy zostala zachovaná v znení už zrušeného zákona o ISVS ako: „informačný systém v pôsobnosti správcu podporujúci služby verejnej správy, služby vo verejnom záujme alebo verejné služby. “ V prípade pojmu informačný systém došlo k zmene, nakol'ko informačný systém predstavuje v zmysle $\S 2$ ods. 2 zákona o ITVS: „funkčný celok zabezpečujúci ciel'avedomú a systematickú informačnú činnost' prostredníctvom technických prostriedkov a programových prostriedkov. “42 $\mathrm{V}$ porovnaní s definíciou pojmu informačný systém $\mathrm{v}$ zmysle zrušeného zákona o ISVS nemusia byt̉ technické prostriedky a programové prostriedky súčastou informačného systému a taktiež tieto prostriedky nemôžu poskytovat iný informačný systém.

Bezpečnosṫ ITVS je v zákone o ITVS upravená v § 18 až § 23. Predmetný zákon upravuje bezpečnost' ITVS v oblasti:

- plánovania a organizácie (§ 19),

${ }^{42} \mathrm{~V}$ zmysle $\S 2$ ods. 1 písm. a) zákona o ISVS bol informačný systém definovaný ako: ,funkčný celok zabezpečujúci ciel'avedomú a systematickú informačnú činnost' prostredníctvom technických prostriedkov a programových prostriedkov, ktoré sú súčastou informačného systému alebo ktoré informačnému systému poskytuje iný informačný systém. “ 
- obstarávania a implementácie (§ 20),

- prevádzky, servisu a podpory (§ 21),

- monitoringu a hodnotenia (§ 22),

V § 18 zákona o ITVS sú základné ustanovenia týkajúce sa situácie kedy je správca aj PZS v zmysle zákona o KB. V § 23 predmetného zákona sú upravené osobitné opatrenia na úseku bezpečnosti ITVS (napr. bezpečnostný projekt).

Správcom ITVS je v zmysle $\S 2$ ods. 5 zákona o ITVS ten orgán riadenia $^{43}$, ktorého za správcu ITVS ustanoví zákon alebo je ustanovený na základe zákona o ITVS. Povinnost správcu zabezpečit riadenie bezpečnosti je zakotvená v § 14 ods. 1 písm. i) zákona o ITVS. V súvislosti s bezpečnostnými opatreniami je správca povinný:

- identifikovat potrebné bezpečnostné opatrenia (§ 19 ods. 1 písm. e) zákona o ITVS),

- určit prostriedky na zabezpečenie implementácie a riadneho fungovania bezpečnostných opatrení (§ 19 ods. 1 písm. h) zákona o ITVS),

- realizovat bezpečnostné opatrenia (§ 19 ods. 3 písm. c) zákona o ITVS).

Z pohl'adu správcu ITVS bude dôležité, aké bezpečnostné opatrenia musí prijał a realizovat a taktiež, ktorý právny predpis má aplikovat pri prijímaní konkrétnych bezpečnostných opatrení. V zmysle § 18 ods. 1 zákona o ITVS je správca, ktorý je zároveň aj PZS povinný prijat a realizovat bezpečnostné opatrenia vo vztahu k ISVS $\mathrm{v}$ jeho správe v závislosti od klasifikácie informácií a kategorizácie sietí a informačných systémov v zmysle § 20 zákona o KB. Inými slovami, vo všeobecnosti platí, ak je správca aj PZS v zmysle zákona o KB, prijíma a realizuje bezpečnostné opatrenia v zmysle zákona o KB.

Povinnosti správcov ITVS v oblasti bezpečnosti ITVS budú detailne upravené vo vykonávacom právnom predpise, ktorý nahradí výnos Ministerstva financií Slovenskej republiky č. 55/2014 Z. z. o štandardoch

43 Taxatívny zoznam orgánov riadenia je uvedený v $§ 5$ ods. 2 zákona o ITVS. 
pre informačné systémy verejnej správy. Obsah bezpečnostných opatrení v novej vyhláške by mal reflektovat už existujúce bezpečnostné opatrenia, ktoré sú správcovia povinní realizovat'.

\subsection{NOVÁ VYHLÁŠKA}

Dôležitým aspektom, ktorý ovplyvní vytvorenie právneho rámca bezpečnosti ITVS, bude prijatie vykonávacieho právneho predpisu, konkrétne vyhlášky. Predmetná vyhláška bude v zmysle § 31 písm. a) a i) zákona o ITVS upravovat:

- jednotlivé kategórie ITVS a podrobnosti o spôsobe zarad'ovania do týchto kategórií,

- podrobnosti o bezpečnosti ITVS podl'a $\S 18$ až 23, obsahu bezpečnostných opatrení, obsahu a štruktúre bezpečnostného projektu a rozsah bezpečnostných opatrení v závislosti od klasifikácie informácií a od kategorizácie sietí a informačných systémov.

Klasifikácia informácii je prejavom hodnoty a statusu informácie danej organizácie. S tým priamo súvisí aj určenie, kto je vlastníkom informácií. ${ }^{44}$ Jednotlivé kategórie ITVS a podrobnosti o spôsobe zarad’ovania do týchto kategórií sa vykoná v zmysle $\S 31$ písm. a) zákon o ITVS s použitím klasifikácie informácií a kategorizácie sietí a informačných systémov v zmysle zákona o KB. ${ }^{45}$

V súvislosti s klasifikáciou informácií vznikajú správcovi v zmysle zákona o ITVS viacero povinností. Správca v zmysle § 19 ods. 1 písm. c) zákona o ITVS zavedie a udržiava systém riadenia informačnej bezpečnosti, ktorý zabezpečí identifikovanie aktív v ITVS. Navyše správca v zmysle $§ 15$ ods. 8 písm. a) a c) zákona o ITVS identifikuje a udržiava zoznam svojich aktív a taktiež identifikuje časti aktív, ktorých nedostupnost̉ alebo znížená

\footnotetext{
44 WONG, H. Cyber Security: Law and Guidance. Bloomsbury Professional, 2018, s. 456.

45 Bližšie pozri: vyhláška č. $362 / 2018$ Z. z. ktorou sa ustanovuje obsah bezpečnostných opatrení, obsah a štruktúra bezpečnostnej dokumentácie a rozsah všeobecných bezpečnostných opatrení.
} 
kvalita má zásadný vplyv na poskytovanie služieb verejnej správy, služieb vo verejnom záujme alebo verejných služieb. ${ }^{46}$

V súvislosti s kategorizáciou ISVS platí, že správca má v zmysle § 19 ods. 5 písm. a) zákona o ITVS povinnost’ určit kategóriu ISVS, do ktorej bude z hladiska klasifikácie informácií a kategorizácie sietí a informačných systémov patrit už pri plánovaní vytvorenia alebo nadobudnutí ISVS.

V súvislosti $s$ bezpečnostným projektom platí, že správca je povinný v zmysle § 23 ods. 2 zákona o ITVS vypracovat bezpečnostný projekt vždy pre ISVS, ktorý je z pohl’adu klasifikácie informácií a kategorizácie sietí a informačných systémov v najvyššej kategórii z hladiska jeho významnosti, funkcie a účelu použitia s ohladom na potrebu zabezpečenia ochrany dôvernosti a integrity a zabezpečenia dostupnosti a úrovne činností vykonávaných s jeho použitím. Inými slovami, správca je povinný vypracovat bezpečnostný projekt pre ITVS $\mathrm{v}$ jeho pôsobnosti, ak je predmetná ITVS zaradená v najvyššej kategórii. Výnimkou z tohto pravidla je situácia, kedy bezpečnostný audit alebo hodnotenie zranitel'nosti vykonané orgánom vedenia zistí riziko alebo hrozbu pre ITVS. V takomto prípade je správca povinný v zmysle $\S 23$ ods. 3 písm. d) zákona o ITVS vypracovat bezpečnostný projekt bez ohl’adu na kategorizáciu ITVS.

\subsection{BEZPEČNOSŤ ISVS V ZÁKONE O KB}

$\mathrm{Na}$ bezpečnost' ISVS sa možno pozerat aj z pohladu zákona o KB. Predmetný zákon stanovil, že medzi základné služby možno zaradit aj ISVS. Národný bezpečnostný úrad (d’alej len „NBÚ“) zarad’uje základnú službu ISVS, do zoznamu základných služieb a jej prevádzkovatel’a do registra PZS v spolupráci s príslušným ústredným orgánom. Príslušným ústredným orgánom pre oblast' ISVS je Úrad podpredsedu vlády Slovenskej republiky pre investície a informatizáciu (d’alej len „ÚPVII“), ktorý má v sektore verejná správa $\mathrm{v}$ pôsobnosti podsektor ISVS.

V praxi v súčasnosti zatial nedochádza $\mathrm{k}$ zarad’ovaniu všetkých ISVS do zoznamu základných služieb a ich správcov do registra PZS, čo odzrkadluje

46 Bližšie k pojmom služba verejnej správy, služba vo verejnom záujme a verejná služba pozri $\S 3$ zákona o ITVS. 
požiadavku smernice NIS na PZS, ktorý má poskytovat’ službu, ktorá má zásadný význam z hl’adiska zachovania kl’účových spoločenských a/alebo hospodárskych činností. ${ }^{47} \mathrm{Ak}$ by došlo k zaradeniu všetkých ISVS do zoznamu základných služieb, nebola by spomínaná požiadavka naplnená, nakol'ko mnoho ISVS neposkytuje službu, ktorá má zásadný význam z hladiska zachovania kl’účových spoločenských a/alebo hospodárskych činností.

Konkrétne bezpečnostné opatrenia, ktoré musí PZS splnit sú stanovené v § 20 zákona o KB a vyhláške NBÚ č. 362/2018 Z. z. ktorou sa ustanovuje obsah bezpečnostných opatrení, obsah a štruktúra bezpečnostnej dokumentácie a rozsah všeobecných bezpečnostných opatrení.

\subsubsection{POSTAVENIE A POVINNOSTI PZS}

V súvislosti s vyššie uvedeným je potrebné ozrejmit', akým spôsobom môže byt' správca ITVS zaradený do registra PZS a jeho ISVS do zoznamu základných služieb. V zmysle zákona o KB existuje niekol'ko spôsobov ako dôjde k zaradeniu základnej služby do príslušného zoznamu a zaradeniu PZS do príslušného registra. ${ }^{48}$

V prípade základných služieb a ich prevádzkovatel’ov platí, že ak entita zistí, že došlo k prekročeniu identifikačných kritérií prevádzkovanej služby a takáto entita patrí do niektorého zo sektorov podla prílohy č. 1 zákona o KB, je povinná urobit oznámenie do 30 dní odo dňa, ked’ sa o prekročení identifikačných kritérií dozvedela. Takéto oznámenie obsahuje konkrétne informácie a je adresované NBÚ. Právny základ pre zaradenie základnej služby do zoznamu základných služieb a PZS do registra PZS závisí od jednotlivých druhov základných služieb.

Slovenský zákonodarca definuje tri druhy základných služieb. V zmysle § 3 písm. k) zákona o KB je základnou službou služba, ktorá je zaradená v zozname základných služieb a:

47 Pozri čl. 5 ods. 2 smernice NIS.

48 PZS je v zmysle § 19 ods. 1 zákona o KB povinný do šiestich mesiacov odo dňa oznámenia o zaradení do registra PZS prijat’ a dodržiavať všeobecné bezpečnostné opatrenia najmenej v rozsahu bezpečnostných opatrení podla $\S 20$ a sektorové bezpečnostné opatrenia, ak sú prijaté. 
A. závisí od sietí a informačných systémov a je činnostou aspoň $\mathrm{v}$ jednom sektore alebo podsektore podla prílohyč. 1 zákona o KB,

B. je informačným systémom verejnej správy ${ }^{49}$, alebo

C. je prvkom kritickej infraštruktúry ${ }^{50}$.

V prípade ak ide o zaradenie základnej služby typu A platí, že NBÚ zaradí túto službu do zoznamu základných služieb a jej prevádzkovatel’a do registra PZS:

a) na základe oznámenia prevádzkovatel’om tejto služby,

b) na základe podnetu ústredného orgánu, ak došlo k prekročeniu identifikačných kritérií prevádzkovanej služby podla $\S 18$ zákona o KB,

c) z vlastnej iniciatívy, ak sa NBÚ dozvedel o prekročení identifikačných kritérií prevádzkovanej služby podla $\S 18$ zákona o KB a nedošlo $\mathrm{k}$ postupu podla písmena a) alebo písmena b). ${ }^{51}$

V prípade základných služieb typu $B$ (služba ako ISVS) platí, že NBÚ v spolupráci s príslušným ústredným orgánom zaradí základnú službu do zoznamu základných služieb a jej prevádzkovatel’a do registra PZS. ${ }^{52}$

V súvislosti so základnými službami typu C platí, že NBÚ zaradí takúto základnú službu do zoznamu základných služieb a jej prevádzkovatel’a do registra PZS zo zákona. ${ }^{53}$

Zaradenie základnej služby do zoznamu základných služieb a jej prevádzkovatel’a do registra PZS oznámi NBÚ prevádzkovatel’ovi tejto služby prostredníctvom jednotného informačného systému kybernetickej bezpečnosti. $^{54}$

${ }^{49} \S 2$ ods. 1 písm. b) zákona č. 275/2006 Z. z. o informačných systémoch verejnej správy a o zmene a doplnení niektorých zákonov.

50 § 2 písm. a) zákona č. 45/2011 Z. z. o kritickej infraštruktúre.

$51 \S 17$ ods. 2 zákona o KB.

52 Tamtiež, § 17 ods. 3.

53 Tamtiež, $\S 17$ ods. 4.

${ }^{54}$ Tamtiež, § 17 ods. 5. Oznámenie nemá charakter individuálneho právneho aktu. Na zaradenie služby do zoznamu základných služieb a jej prevádzkovatela do registra PZS sa nevztahuje zákon č. 71/1967 Zb. o správnom konaní (správny poriadok), čo znamená, že zaradený subjekt nemôže použit opravné prostriedky v zmysle správneho poriadku. 
Aby došlo k zaradeniu základnej služby do zoznamu základných služieb a jej prevádzkovatel'a do registra PZS, musí príslušná základná služba, ktorú poskytuje entita prekročit identifikačné kritériá prevádzkovanej služby. V zmysle $\S 18$ zákona o KB sa identifikačné kritéria prevádzkovanej služby delia na dopadové kritéria a špecifické sektorové kritériá.

Dopadové kritériá vychádzajú z článku 6 smernice NIS, ktorý upravuje faktory pre určenie závažnosti rušivého vplyvu. Podrobnosti o dopadových a špecifických sektorových kritériách pre základnú službu sú upravené vo vyhláške NBÚ č. 164/2018 Z. z., ktorou sa určujú identifikačné kritériá prevádzkovanej služby (kritériá základnej služby). ${ }^{55} \mathrm{Na}$ tomto mieste je potrebné podotknút, že európsky zákonodarca určuje identifikačné kritéria PZS a nie pre základné služby. Avšak slovenský zákonodarca upravuje v zákone KB a predmetnej vyhláške identifikačné kritéria prevádzkovanej služby a ak entita tieto kritéria prekročí následne možno hovorit’ o tom, že má postavenie PZS.

Z praktického hl'adiska je však problematickejšia skutočnost', že vyššie uvedená vyhláška určuje identifikačné kritériá len pre PZS typu A. Inými slovami, pri prevádzkovatel’och základnej služby typu B a C sa neskúmajú dopadové kritériá, ktoré vychádzajú z článku 6 smernice NIS. V tejto súvislosti je evidentný jasný rozpor s článkom 5 ods. 2 smernice NIS, v zmysle ktorého musí PZS kumulatívne spĺn̆at tieto kritériá:

- subjekt poskytuje službu, ktorá má zásadný význam z hl'adiska zachovania kl’účových spoločenských a/alebo hospodárskych činností;

- poskytovanie tejto služby je závislé od sietí a informačných systémov a

- incident by mal závažný rušivý vplyv na poskytovanie uvedenej služby.

${ }^{55}$ V zmysle $\S 2$ predmetnej vyhlášky platí, že: „prevádzkovaná služba spĺn̆a identifikačné kritériá základnej služby, ak splńa aspoň jedno dopadové kritérium a aspoň jedno špecifické sektorové kritérium, ak je uvedené v prílohe č. 1." Avšak, v zmysle $\S 18$ ods. 4 zákona o KB platí, že: „ak prevádzkovatel služby podl’a prílohy č. 1 zistí, že došlo $k$ prekročeniu špecifických sektorových kritérí, oznámi to úradu do 30 dní odo dňa, ked' prekročenie zistil v rozsahu podl'a $\S 17$ ods. 5 aj v prípade, ak neprekročí dopadové kritériá. " Neskoršie citované ustanovenie nevyžaduje naplnenie dopadového kritéria, čo je v rozpore so smernicou NIS. 
V prípade ak sa neskúma posledné spomenuté kritérium, a teda závažný rušivý vplyv, nemožno hovorit o PZS v zmysle smernice NIS.

Skutočnost či správca ISVS bude zároveň aj v postavení PZS v zmysle zákona o KB, bude mat dopad najmä na to či tento subjekt bude pri realizácii bezpečnostných opatrení postupovat v zmysle zákona o ITVS alebo zákona o KB. Nejasnost̉ tejto situácie možno demonštrovat na prepojení zákona o ITVS a zákona o KB.

\subsection{PREPOJENIE ZÁKONA O ITVS A ZÁKONA O KB}

Ako už bolo spomenuté, ak je správca ITVS aj v postavení PZS v zmysle zákona o $\mathrm{KB}$, prijíma a realizuje bezpečnostné opatrenia $\mathrm{v}$ zmysle zákona o KB. Avšak môže dôjst k situácii, kedy správca v pozícii PZS nebude realizovat bezpečnostné opatrenia $\mathrm{v}$ zmysle zákona o KB ale $\mathrm{v}$ zmysle zákona o ITVS.

V zmysle $\S 18$ ods. 2 zákona o ITVS platí, že: „obsah bezpečnostných opatrení vo vztahu k informačným systémom verejnej správy a spôsob a rozsah ich prijímania a realizácie $v$ súlade s osobitným predpisom. “ Týmto osobitným predpisom je zákon o KB, konkrétne jeho $\S 2$ ods. 2 písm. e), v zmysle ktorého sa zákon o KB nevztahuje na: „požiadavky na zabezpečenie sietí a informačných systémov $v$ sektore podl'a osobitného predpisu, ak ich cielom je dosiahnut vyššiu úroveň bezpečnosti sietí a informačných systémov ako podla tohto zákona." Predmetným osobitným predpisom je už zrušený zákon o ISVS. ${ }^{56}$ Na základe vyššie uvedeného možno konštatovat', že v prípade ak zákon o ITVS stanoví pre správcu, ktorý je zároveň aj PZS, striktnejšie bezpečnostné opatrenia, bude musiet’ správca prijat’ a realizovat bezpečnostné opatrenia $\mathrm{v}$ zmysle zákona o ITVS. $\mathrm{V}$ praxi to bude pre správcu, ktorý je aj PZS znamenat', že bude musiet porovnávat bezpečnostné opatrenia $\mathrm{v}$ zmysle zákona o KB a zákona o ITVS.

V tejto súvislosti by bolo viac ako vhodné, aby ÚPVII ako orgán vedenia v zmysle zákona o ITVS prijal výkladové stanoviská v zmysle § 9 ods. 1 písm. a) zákona o ITVS alebo metodické usmernenia v zmysle $\S 8$ ods. 1

${ }^{56}$ V zmysle § 33 ods. 1 zákona o ITVS: „informačné systémy verejnej správy podl’a doterajších predpisov sú informačnými systémami verejnej správy podl’a tohto zákona." 
písm. a) zákona o ITVS. Výkladové stanoviská alebo metodické usmernenia by mohli prispiet $\mathrm{k}$ tomu, aby správcovia vedeli identifikovat', prijat a realizovat konkrétne bezpečnostné opatrenia $\mathrm{v}$ zmysle príslušných právnych predpisov, čo by mohlo dopomôct $\mathrm{k}$ právnej istote.

Ak správca nie je PZS, prijíma a realizuje bezpečnostné opatrenia v zmysle zákona o ITVS.

Možno konštatovat, že bezpečnostné opatrenia upravené v zákone o ITVS sa aplikujú na ISVS ktoré neboli zaradené do zoznamu základných služieb v zmysle zákona o KB a taktiež na tie, ktoré boli zaradené do zoznamu základných služieb $\mathrm{v}$ zmysle zákona o KB, ale bezpečnostné opatrenia stanovené v zákone o ITVS majú za ciel' dosiahnut vyššiu úroveň bezpečnosti sietí a informačných systémov ako v zákone o KB.

\section{HLÁSENIE BEZPEČNOSTNÝCH INCIDENTOV}

Akokolvek striktné bezpečnostné opatrenia nemôžu zabránit tomu, že hrozba (napr. v podobe kybernetického útoku) zneužije zranitel'nost ISVS a spôsobí narušenie požadovaného stavu aktíva, čím dôjde $\mathrm{k}$ bezpečnostnému incidentu. Takáto situácia znamená, že správca ITVS je povinný takýto bezpečnostný incident hlásit konkrétnej entite. Správca je povinný hlásił kybernetické bezpečnostné incidenty $\mathrm{v}$ zmysle zákona o ITVS a v prípade ak je aj PZS, tak aj kybernetické bezpečnostné incidenty v zmysle zákona o KB. Navyše, za určitých podmienok, môže kybernetický bezpečnostný incident spôsobit aj porušenie ochrany osobných v zmysle nariadenia Európskeho parlamentu a Rady (EÚ) 2016/679 z 27. apríla 2016 o ochrane fyzických osôb pri spracúvaní osobných údajov a o vol'nom pohybe takýchto údajov, ktorým sa zrušuje smernica 95/46/ES (všeobecné nariadenie o ochrane údajov) (d’alej len „GDPR“).

\subsection{HLÁSENIE KYBERNETICKÝCH BEZPEČNOSTNÝCH INCIDENTOV}

\section{ZMYSLE ZÁKONA O KB}

PZS je v zmysle § 19 ods. 6 písm. b) zákona o KB povinný bezodkladne hlásit závažný kybernetický bezpečnostný incident. Rovnakú povinnost’ musí PZS splnit aj v zmysle $\S 24$ ods.1 predmetného zákona. PZS 
identifikuje závažný kybernetický bezpečnostný incident na základe presiahnutia kritérií pre jednotlivé kategórie závažných kybernetických bezpečnostných incidentov. $\mathrm{V}$ zmysle $\S 24$ ods. 2 zákona o KB sa závažné kybernetické bezpečnostné incidenty členia na kategórie prvého, druhého a tretieho stupňa. Stanovenie konkrétneho stupňa závisí od nasledujúcich faktorov:

- počtu používatelov základnej služby alebo digitálnej služby zasiahnutých kybernetickým bezpečnostným incidentom,

- dížky trvania kybernetického bezpečnostného incidentu,

- geografického rozšírenia kybernetického bezpečnostného incidentu,

- stupňa narušenia fungovania základnej služby alebo digitálnej služby,

- rozsahu vplyvu kybernetického bezpečnostného incidentu na hospodárske alebo spoločenské činnosti štátu. ${ }^{57}$

Presná špecifikácia kritérií pre jednotlivé kategórie závažných kybernetických bezpečnostných incidentov je predmetom vyhlášky NBÚ č. 165/2018 Z. z. ktorou sa určujú identifikačné kritériá pre jednotlivé kategórie závažných kybernetických bezpečnostných incidentov a podrobnosti hlásenia kybernetických bezpečnostných incidentov. PZS má povinnost hlásił kybernetické bezpečnostné incidenty prostredníctvom jednotného informačného systému kybernetickej bezpečnosti. ${ }^{58}$

Na tomto mieste je potrebné podotknút, že v zmysle čl. 14 ods. 3 smernice NIS má PZS povinnost̉ bezodkladne hlásit incidenty, ktoré majú závažný vplyv na kontinuitu základných služieb, ktoré poskytujú. S cielom určit závažnost̉ vplyvu incidentu sa zohl'adňujú konkrétne parametre osobitne pre základné služby a digitálne služby.

Parametre pre určenie závažnosti vplyvu incidentu na kontinuitu základných služieb, ktoré PZS poskytujú sú najmä: počet používatel’ov postihnutých narušením základnej služby; dížka trvania incidentu a geografické rozšírenie z hladiska oblasti, ktorú incident postihol. ${ }^{59}$

\footnotetext{
§ 24 ods. 2 písm. a) - e) zákona o KB.

$58 \S 24$ ods. 4 a $\S 25$ ods. 1 zákona o KB.

59 Čl. 14 ods. 4 smernice NIS.
} 
Pre určenie závažnosti vplyvu na poskytované digitálne služby sú najmä tieto parametre: počet používatel'ov postihnutých incidentom, najmä používatel'ov využívajúcich danú službu na účely poskytovania vlastných služieb; dížka trvania incidentu; geografické rozšírenie z hl'adiska oblasti, ktorú incident postihol; stupeň narušenia fungovania služby; rozsah vplyvu na hospodárske a spoločenské činnosti. ${ }^{60}$

V zákone o KB boli parametre pre určenie závažnosti vplyvu incidentu na kontinuitu základných služieb a pre určenie závažnosti vplyvu na poskytované digitálne služby v zmysle smernice NIS spojené do jedného, a to pre účely stanovenia stupňa závažného kybernetického bezpečnostného incidentu.

\subsubsection{JEDNOTNÝ INFORMAČNÝ SYSTÉM KYBERNETICKEJ BEZPEČNOSTI} Jednotný informačný systém kybernetickej bezpečnosti predstavuje základný komunikačný kanál medzi NBÚ a ostatnými entitami v oblasti kybernetickej bezpečnosti. NBÚ je správcom a prevádzkovatelom predmetného informačného systému. NBÚ sprístupní jednotný informačný systém kybernetickej bezpečnosti do 18 mesiacov od účinnosti predmetného zákona. $^{61}$

Jednotný informačný systém kybernetickej bezpečnosti obsahuje komunikačný systém pre hlásenie a riešenie kybernetických bezpečnostných incidentov a centrálny systém včasného varovania. V súvislosti sprístupom kjednotnému informačnému systému kybernetickej bezpečnosti má tento informačný systém verejnú čast̉ a neverejnú čast'. Verejná čast’ obsahuje príslušné registre PZS, poskytovatel’ov digitálnych služieb, ústredných orgánov, kybernetických bezpečnostných incidentov a zoznamy základných služieb, digitálnych služieb a akreditovaných jednotiek CSIRT. ${ }^{62}$ Do neverejnej časti jednotného informačného systému kybernetickej bezpečnosti majú prístup $\mathrm{v}$ elektronickej forme, $\mathrm{v}$ reálnom čase a v rozsahu určenom NBÚ alebo

60 Tamtiež, čl. 16 ods. 4 .

61 § 34 ods. 1 zákona o KB.

62 Tamtiež $\S 8$ ods. 2. [on-line] https://www.nbu.gov.sk/kyberneticka-bezpecnost/jednotnyinformacny-system-kybernetickej-bezpecnosti/index.html [citované 30.9.2019] 
osobitným predpisom na základe vecnej pôsobnosti ústredný orgán, jednotka CSIRT (zaradená v zozname akreditovaných jednotiek CSIRT), PZS, poskytovatel’ov digitálnych služieb, Národná banka Slovenska, Úrad na ochranu osobných údajov Slovenskej republiky a iný orgán verejnej moci rozhodnutím NBÚ ${ }^{63}$

Z dikcie zákona o KB vyplýva, že jednotný informačný systém kybernetickej bezpečnosti je primárnym komunikačným kanálom. Avšak, je potrebné mysliet aj na situácie, kedy by jednotný informačný systém kybernetickej bezpečnosti nemohol plnit svoj účel, napr. z dôvodu incidentu, ktorý by ochromil alebo znefunkčnil jeho prevádzku. Predpokladám, že pre tieto prípady by sa mal aplikovat $\S 24$ ods. 6 zákona o KB. V zmysle predmetného ustanovenia platí, že NBÚ môže uzatvorit písomnú zmluvu o spôsobe a forme hlásenia kybernetických bezpečnostných incidentov s PZS. Podobným spôsobom môže NBÚ uzavriet' zmluvu aj s poskytovatel’om digitálnych služieb. ${ }^{64}$

\subsection{HLÁSENIE KYBERNETICKÝCH BEZPEČNOSTNÝCH INCIDENTOV V ZMYSLE ZÁKONA O ITVS}

V zmysle $\S 23$ ods. 3 zákona o ITVS sú orgán riadenia podla $\S 5$ ods. 2 písm. a) a b $)^{65}$ a rozpočtová organizácia a príspevková organizácia $v$ jeho zriad'ovatel'skej pôsobnosti povinní:

- ak sú zaradení do registra PZS podla osobitného predpisu (ISVS ako základná služba podla zákona o KB), nahlasovat spôsobom podla osobitného predpisu (prostredníctvom jednotného informačného systému kybernetickej bezpečnosti) aj kybernetický bezpečnostný incident, na

63 Tamtiež, $\S 8$ ods. 5 .

64 Tamtiež, § 25 ods. 3.

65 Orgán riadenia je podla § 5 ods. 2 písm. a) a b) zákona o ITVS: ministerstvo a ostatný ústredný orgán štátnej správy, Generálna prokuratúra Slovenskej republiky, Najvyšší kontrolný úrad Slovenskej republiky, Úrad pre dohlad nad zdravotnou starostlivostou, Úrad na ochranu osobných údajov Slovenskej republiky, Úrad pre reguláciu elektronických komunikácií a poštových služieb, Dopravný úrad, Úrad pre reguláciu sietových odvetví a iný štátny orgán. 
ktorý sa nevztahuje povinnost' nahlasovania podla osobitného predpisu ( $§ 24$ ods. 1 zákona o KB),

- ak nie sú zaradení do registra PZS, nahlasujú takýto kybernetický bezpečnostný incident ÚPVII ním určeným spôsobom,

- určit jeden kontaktný bod na nahlasovanie kybernetických bezpečnostných incidentov.

V zmysle $\S 33$ ods. 5 zákona o ITVS platí, že orgán riadenia podla § 5 ods. 2 písm. a) a b) a rozpočtová organizácia a príspevková organizácia v jeho zriad'ovatel'skej pôsobnosti, ktorí sú zaradení do registra PZS podla osobitného predpisu, nahlasujú do uplynutia 30 dní odo dňa zriadenia a uvedenia do prevádzky jednotného informačného systému kybernetickej bezpečnosti ${ }^{66}$ kybernetický bezpečnostný incident podla $§ 23$ ods. 3 písm. a) orgánu vedenia, ktorým je ÚPVII, ním určeným spôsobom.

Zákon o ITVS ukladá v § 23 ods. 4 zákona o ITVS plnit povinnosti v zmysle $\S 23$ ods. 3 písm. a) aj ostatným orgánom riadenia ${ }^{67}$. Inými slovami, aj ostatné orgány riadenia, ak sú zaradení do registra PZS, sú

${ }^{66}$ JISKB musí byt uvedený do prevádzky najneskôr 18.10 .2019 v zmysle $\S 34$ ods. 1 zákona o KB.

${ }^{67}$ Ostatné orgány riadenia možno chápat ako tie, ktoré neboli uvedené v § 23 ods. 3, a teda ide o orgány riadenia podla $\S 5$ ods. 2 písm. c) - h):

„c)obec a vyšší územný celok,

d)Kancelária Národnej rady Slovenskej republiky, Kancelária prezidenta Slovenskej republiky, Kancelária Ústavného súdu Slovenskej republiky, Kancelária Najvyššieho súdu Slovenskej republiky, Kancelária Súdnej rady Slovenskej republiky, Kancelária verejného ochrancu práv, Úrad komisára pre deti, Úrad komisára pre osoby so zdravotným postihnutím, Ústav pamäti národa, Sociálna poistovña, zdravotné poistovne, Tlačová agentúra Slovenskej republiky, Rozhlas a televízia Slovenska, Rada pre vysielanie a retransmisiu,

e)právnická osoba $v$ zriad'ovatel'skej pôsobnosti alebo zakladatel'skej pôsobnosti orgánu riadenia uvedeného v písmenách a) až d),

f)komora regulovanej profesie a komora, na ktorú je prenesený výkon verejnej moci s povinným členstvom,

g)osoba neuvedená $v$ písmenách a) až f) okrem Národnej banky Slovenska, na ktorú je prenesený výkon verejnej moci alebo ktorá plní úlohy na úseku preneseného výkonu štátnej správy podla osobitných predpisov,

h)záujmové združenie právnických osôb DataCentrum elektronizácie územnej samosprávy Slovenska, ktorého jedinými členmi sú Ministerstvo financií Slovenskej republiky a Združenie miest a obcí Slovenska.“ 
povinné nahlasovat prostredníctvom jednotného informačného systému kybernetickej bezpečnosti aj kybernetický bezpečnostný incident, na ktorý sa nevztahuje povinnost̉ nahlasovania podla zákona o KB. Taktiež, ak nie sú zaradení do registra PZS, nahlasujú kybernetický bezpečnostný incident, ktorý nespíňa kritériá podla zákona o K B ÚPVII ním určeným spôsobom. A v neposlednom rade sú ostatné orgány riadenia povinné určit jeden kontaktný bod na nahlasovanie kybernetických bezpečnostných incidentov.

V prípade ak správca nie je PZS v zmysle zákona o KB, má možnost nahlasovat aj závažné kybernetické bezpečnostné incidenty podla $\S 24$ ods. 1 zákona o KB, resp. príslušnej vyhlášky, a to prostredníctvom inštitútu dobrovol'ného hlásenia kybernetických bezpečnostných incidentov $\mathrm{v}$ zmysle § 26 ods. 1 zákona o KB. V recitáli 67 smernice NIS sa uvádza, že subjekty, ktoré neboli určené ako PZS a nie sú ani poskytovatel’mi digitálnych služieb, majú možnost dobrovolne oznamovat incidenty, ktoré majú významný vplyv na služby, ktoré poskytujú, ak sa domnievajú, že je vo verejnom záujme oznámit, že k takýmto incidentom došlo.

\subsection{PORUŠENIE OCHRANY OSOBNÝCH ÚDAJOV V ZMYSLE GDPR}

V praxi môže nastat situácia, kedy si ten istý subjekt bude plnit svoju oznamovaciu povinnost $\mathrm{v}$ zmysle zákona o $\mathrm{KB}$, resp. zákona o ITVS a zároveň si musí splnit oznamovaciu povinnost̉ v zmysle GDPR. Inými slovami, subjekt bude nahlasovat rovnakú skutočnost̉ rôznym inštitúciám. V podmienkach Slovenskej republiky by išlo o splnenie si oznamovacej povinnosti voči NBÚ, resp. ÚPVII a Úradu na ochranu osobných údajov. ${ }^{68}$

68 Príkladom entity, ktorá môže byt správcom v zmysle zákona o ITVS a zároveň aj prevádzkovatel’om základných služieb $\mathrm{v}$ zmysle zákona $\mathrm{KB}$ a prevádzkovatelom $\mathrm{v}$ zmysle GDPR je napr. Ministerstvo vnútra Slovenskej republiky vo vztahu k informačnému systému s názvom Evidencia vozidiel. 
GDPR ukladá prevádzkovatel'ovi ${ }^{69}$ a sprostredkovatel'ovi $^{70}$ povinnost $^{2}$ oznamovat porušenie ochrany osobných údajov. ${ }^{71} \mathrm{Za}$ porušenie ochrany osobných údajov považuje: „porušenie bezpečnosti, ktoré vedie $k$ náhodnému alebo nezákonnému zničeniu, strate, zmene, neoprávnenému poskytnutiu osobných údajov, ktoré sa prenášajú, uchovávajú alebo inak spracúvajú, alebo neoprávnený prístup $k$ nim “. ${ }^{72}$

Je potrebné podotknút, že k splneniu si oznamovacej povinnosti v zmysle GDPR dôjde len v prípadoch, ked' došlo k porušeniu ochrany osobných údajov.

V nasledujúcej tabul'ke uvádzam prehl'ad oznamovacích povinností jednotlivých subjektov v zmysle GDPR.

\begin{tabular}{|c|c|c|}
\hline Povi & Lehota & Výnimka \\
\hline $\begin{array}{c}\text { Prevádzkovatel' } \\
\text { oznamuje } \\
\text { dozornému orgánu } \\
\text { (čl. } 33 \text { ods. } 1 \text { GDPR) }\end{array}$ & $\begin{array}{l}\text { Bez zbytočného odkladu } \\
\text { a podla možnosti } \\
\text { najneskôr do } 72 \text { hodín po } \\
\text { tom, čo sa o porušení } \\
\text { ochrany osobných údajov } \\
\text { dozvedel }\end{array}$ & $\begin{array}{l}\text { Oznámenie sa nevyžaduje, ked' } \\
\text { nie je pravdepodobné, že } \\
\text { porušenie ochrany osobných } \\
\text { údajov povedie k riziku pre práva } \\
\text { a slobody fyzických osôb. }\end{array}$ \\
\hline $\begin{array}{c}\text { Sprostredkovatel' } \\
\text { oznamuje } \\
\text { prevádzkovatel'ovi } \\
\text { (čl. } 33 \text { ods. } 2 \text { GDPR) }\end{array}$ & $\begin{array}{l}\text { Bez zbytočného odkladu } \\
\text { po tom, čo sa o porušení } \\
\text { ochrany osobných údajov } \\
\text { dozvedel }\end{array}$ & $\begin{array}{c}\text { Oznámenie sa nevyžaduje, ked' } \\
\text { nie je pravdepodobné, že } \\
\text { porušenie ochrany osobných } \\
\text { údajov povedie k riziku pre práva }\end{array}$ \\
\hline
\end{tabular}

${ }^{69}$ Prevádzkovatel' je v zmysle čl. 4 bodu 7 GDPR definovaný ako: „fyzická alebo právnická osoba, orgán verejnej moci, agentúra alebo iný subjekt, ktorý sám alebo spoločne s inými určí účely a prostriedky spracúvania osobných údajov; v prípade, že sa účely a prostriedky tohto spracúvania stanovujú v práve Únie alebo $v$ práve členského štátu, možno prevádzkovatel'a alebo konkrétne kritériá na jeho určenie určit’v práve Únie alebo v práve členského štátu.“

${ }^{70}$ Sprostredkovatelom je v zmysle čl. 4 bodu 8 GDPR: „fyzická alebo právnická osoba, orgán verejnej moci, agentúra alebo iný subjekt, ktorý spracúva osobné údaje $v$ mene prevádzkovatela."

${ }^{71}$ Bližšie k pojmom prevádzkovatel’ a sprostredkovatel’ pozri: MESARČíK, M. Základné pojmy Nariadenia. In Všeobecné nariadenie o ochrane osobných údajov. Praha: C.H. Beck, 2018, s. 123-186.

72 Čl. 4 ods. 12 GDPR. 


\begin{tabular}{|c|c|c|}
\hline & & a slobody fyzických osôb. \\
\hline $\begin{array}{c}\text { Prevádzkovatel' } \\
\text { oznamuje dotknutej } \\
\text { osobe (čl. } 34 \text { ods. } 1 \\
\text { GDPR) }\end{array}$ & Bez zbytočného odkladu & $\begin{array}{c}\text { Oznámenie sa nevyžaduje ak: } \\
\text { a) prevádzkovatel' prijal } \\
\text { primerané technické } \\
\text { a organizačné ochranné } \\
\text { opatrenia a tieto opatrenia } \\
\text { uplatnil na osobné údaje, ktorých } \\
\text { sa porušenie ochrany osobných } \\
\text { údajov týka, a to najmä tie } \\
\text { opatrenia, na základe ktorých sú } \\
\text { osobné údaje nečitatel'né pre } \\
\text { všetky osoby, ktoré nie sú } \\
\text { oprávnené mat' k nim prístup, } \\
\text { ako je napríklad šifrovanie; } \\
\text { b) prevádzkovatel' prijal následné } \\
\text { opatrenia, ktorými sa zabezpečí, } \\
\text { informované rovnako efektívnym } \\
\text { že vysoké riziko pre práva } \\
\text { a slobody dotknutých osôb } \\
\text { uvedené v odseku } 1 \\
\text { veravdepodobne už nebude mat } \\
\text { dôsledky; } \\
\text { úsilie. V takom prípade dôjde } \\
\text { namiesto toho k informovaniu }\end{array}$ \\
\hline
\end{tabular}

Zdroj: vlastné spracovanie 
K prelínaniu sa oznamovacej povinnosti v zmysle GDPR a zákona o KB, resp. zákona o ITVS, môže dôjst’ v mnohých prípadoch. Ak berieme do úvahy koncept kybernetickej bezpečnosti $\mathrm{v}$ zmysle zákona o KB, kedy konanie, ktoré ohrozuje dostupnost', pravost', integritu alebo dôvernost̉ uchovávaných, prenášaných alebo spracúvaných údajov alebo súvisiacich služieb poskytovaných alebo prístupných prostredníctvom týchto sietí a informačných systémov, by mohlo zároveň spôsobit porušenie ochrany osobných údajov v zmysle GDPR.

V teoretickej rovine možno povedat', že narušenie ochrany osobných údajov v zmysle GDPR sa spája najmä s narušením bezpečnostnej požiadavky súkromnosti, ktorá znamená, že k osobným údajom majú prístup len tie osoby, ktoré majú na to oprávnenie. Na druhej strane, zákon o KB upriamuje pozornost' na bezpečnostné požiadavky ako dôvernost', integrita, dostupnost' a autentickost'. Napr. narušenie integrity služby, poskytovanej prostredníctvom sietí a informačných systémov a údajov, ktoré sú v rámci jej poskytovania spracované, môže znamenat aj porušenie ochrany osobných údajov v zmysle GDPR, nakol'ko v mnohých prípadoch pôjde o narušenie integrity osobných údajov.

Ako už bolo vyššie uvedené, hlásený kybernetický bezpečnostný incident môže mat charakter porušenia ochrany osobných údajov. V praxi by bolo preto vhodné, aby si subjekty mohli plnit oznamovaciu povinnost’ v zmysle zákona o KB, resp. zákona o ITVS a GDPR jedným oznámením. Na tieto účely by mohol slúžit aj jednotný informačný systém kybernetickej bezpečnosti. Takéto riešenie v zásade potvrdzuje aj ust. $\S 8$ ods. 5 písm. e) zákona o KB, v zmysle ktorého má Úrad na ochranu osobných údajov prístup k neverejnej časti jednotného informačného systému kybernetickej bezpečnosti. V tejto súvislosti je potrebné zabezpečit', aby oznamovanie porušenia ochrany osobných údajov, ktoré sa bude vykonávat prostredníctvom oznámenia $\mathrm{v}$ zmysle zákona $\mathrm{o} \mathrm{KB}$, obsahovalo náležitosti oznámenia v zmysle GDPR. Preto je potrebné zabezpečit, aby Úrad na ochranu osobných údajov bol adresátom a spracovatelom len tých údajov, ktoré sa týkajú porušenia ochrany osobných údajov. 
Povinnost̉ hlásit konkrétny typ kybernetických bezpečnostných incidentov, konkrétnym subjektom v zmysle zákona o ITVS, zákona o KB a GDPR uvádzam v nasledujúcej súhrnnej tabul'ke.

\begin{tabular}{|c|c|c|c|c|}
\hline & Zákon o ITVS I & Zákon o ITVS II & Zákon o KB & GDPR \\
\hline Subjekt & $\begin{array}{l}\text { Orgán riadenia } \\
\text { (zároveň aj } \\
\text { PZS) }\end{array}$ & $\begin{array}{l}\text { Orgán riadenia } \\
\text { (nie je PZS) }^{73}\end{array}$ & $\begin{array}{l}\text { PZS (zároveň aj } \\
\text { správca ISVS) }\end{array}$ & Prevádzkovatel' \\
\hline $\begin{array}{l}\text { Druh } \\
\text { bezpečnostnéh } \\
\text { o incidentu (BI) }\end{array}$ & $\begin{array}{c}\text { Kybernetický } \\
\text { BI }\end{array}$ & $\begin{array}{c}\text { Kybernetický } \\
\text { BI }\end{array}$ & $\begin{array}{c}\text { Závažný } \\
\text { kybernetický BI }\end{array}$ & $\begin{array}{l}\text { Porušenie } \\
\text { ochrany } \\
\text { osobných } \\
\text { údajov }\end{array}$ \\
\hline $\begin{array}{l}\text { Komu a akým } \\
\text { spôsobom sa } \\
\text { oznamuje } \\
\text { bezpečnostný } \\
\text { incident (BI) }\end{array}$ & NBÚ (JISKB) & $\begin{array}{l}\text { Orgánu vedenie } \\
\text { (ÚPVII), ním } \\
\text { určeným } \\
\text { spôsobom }\end{array}$ & NBÚ (JISKB) & $\begin{array}{l}\text { Úradu na } \\
\text { ochranu } \\
\text { osobných } \\
\text { údajov }^{74}\end{array}$ \\
\hline Lehota & & & Bezodkladne & $\begin{array}{c}\text { Bez zbytočného } \\
\text { odkladu/72 } \\
\text { hodín }\end{array}$ \\
\hline
\end{tabular}

Zdroj: vlastné spracovanie

\section{ZÁVER}

Pri vhodnom nastavení a realizácii bezpečnostných opatrení v zmysle zákona o ITVS a zákona o KB budú ISVS dostatočne chránené pred rôznymi hrozbami (či už z fyzického sveta alebo z kybernetického priestoru). Avšak, pre dosiahnutie potrebnej úrovne bezpečnosti ISVS je potrebné zabezpečit', aby správcovia tieto opatrenia vedeli identifikovat', prijat a realizovat.

73 Orgán riadenia, ktorý nie je PZS môže hlásit kybernetické bezpečnostné incidenty podla zákona o KB prostredníctvom dobrovol'ného hlásenia.

74 Povinnost' hlásit porušenie ochrany osobných údajov vznikne len za predpokladu, že porušenie ochrany osobných údajov povedie k riziku pre práva a slobody fyzických osôb. 
Prijatie novej legislatívy v oblasti bezpečnosti ISVS je nepochybne krokom vpred, avšak v otázke právnej istoty prináša nová legislatíva niekol'ko problémov. V prvom rade, zarad'ovanie všetkých ISVS do zoznamu základných služieb a ich správcov do registra PZS v zmysle zákona o KB odporuje smernici NIS, nakol'ko nie všetky ISVS, resp. ich správcovia poskytujú službu, ktorá má zásadný význam z pohl’adu zachovania hospodárskych alebo spoločenských činností. Navyše, ak sa pri zarad’ovaní správcov ITVS do registra PZS neskúmajú dopadové kritériá, ktoré vychádzajú z článku 6 smernice NIS, dochádza k jasnému porušeniu smernice NIS.

Prepojenost̉ zákona o ITVS a zákona o KB môže významným spôsobom ovplyvnit dosiahnutie dostatočnej úrovne bezpečnosti ISVS. V praxi môžu nastat’ situácie, kedy budú subjekty v právnom postavení správcov ITVS alebo v právnom postavení PZS v istých momentoch porovnávat’ striktnost̉ bezpečnostných opatrení v zmysle zákona o ITVS a zákona o KB. V tejto súvislosti bude potrebné, aby ÚPVII prijal výkladové stanoviská alebo metodické usmernenia, ktoré by mohli prispiet’ k tomu, aby správcovia vedeli identifikovat', prijat’ a realizovat konkrétne bezpečnostné opatrenia v zmysle príslušných právnych predpisov, čo by mohlo dopomôct’ k právnej istote.

K dosiahnutiu dostatočnej úrovne bezpečnosti ISVS by mohla dopomôct’ aj kontrola realizácie bezpečnostných opatrení a následné sankcionovanie v prípade neplnenia si povinností v zmysle zákona o ITVS a zákona o KB. V tejto súvislosti je potrebné podotknút, že ciel’om zákona o ITVS a zákona o KB nie je represívne pôsobit na správcov a PZS pri nesplnení si povinností, najmä $\mathrm{v}$ podobe nedostatočného realizovania bezpečnostných opatrení, resp. absencie realizovania bezpečnostných opatrení. V tejto súvislosti si dovolím tvrdit, že zákon o ITVS a jeho vykonávací právny predpis bude upravovat len minimálne bezpečnostné opatrenia, ktoré je potrebné prijat a realizovat $\mathrm{v}$ závislosti od konkrétnej kategórie ITVS. Správcovia, ktorých ITVS budú zaradené do vyšších kategórií, budú povinní prijat’ striktnejšie bezpečnostné opatrenia v porovnaní s nižšími kategóriami ITVS. Taktiež je potrebné podotknút, že už v súčasnosti sú správcovia 
povinní plnit v zmysle výnosu Ministerstva financií Slovenskej republiky č. 55/2014 Z. z. o štandardoch pre informačné systémy verejnej správy mnohé bezpečnostné opatrenia.

Predmetom spomínaného vykonávacie právneho predpisu bude taktiež pôsob zaradenia ITVS do konkrétnych kategórií a klasifikácia informácií. Vyhláška taktiež upraví obsah a rozsah bezpečnostných opatrení v závislosti od konkrétnej kategórie ITVS a obsah a štruktúru bezpečnostného projektu.

Ani tie najprísnejšie bezpečnostné opatrenia nemôžu zabránił tomu, aby nedošlo ku kybernetickému bezpečnostnému incidentu. V takýchto prípadoch je zasiahnutý subjekt $\mathrm{v}$ zmysle zákona o ITVS, zákona o KB a GDPR povinný hlásit konkrétny typ bezpečnostného incidentu, konkrétnemu subjektu. Subjekt či už v postavení PZS podla zákona o KB, postavení správcu v zmysle zákona o ITVS alebo postavení prevádzkovatel’a v zmysle GDPR si pred samotným hlásením musí uvedomit, aký typ bezpečnostného incidentu má hlásit', akým spôsobom, akému subjektu a v akej lehote. Bolo by viac ako vhodné, aby konkrétny subjekt mohol urobit jedno hlásenie bezpečnostného incidentu, ktoré by bolo adresované zainteresovaným subjektom. V podmienkach Slovenskej republiky sa ako najvhodnejšie riešenie tejto situácie javí využitie jednotného informačného systému kybernetickej bezpečnosti, prostredníctvom ktorého by sa mohli hlásił kybernetické bezpečnostné incidenty, ktoré nespíňajú kritériá v zmysle zákona o KB, závažné kybernetické bezpečnostné incidenty podla zákona o KB, ako aj oznámenia, ktoré majú charakter porušenia ochrany osobných údajov. Pre dosiahnutia tohto ciela by bolo potrebné zosúladit obsahové náležitosti formulárov, ktoré konkrétne subjekty využívajú pri hlásení konkrétnych typov bezpečnostných incidentov. K jednotnému informačnému systému kybernetickej bezpečnosti, resp. jeho neverejnej časti, kde by boli evidované jednotlivé hlásenia by mal prístup okrem NBÚ, Úradu na ochranu osobných údajov aj ÚPVII. 


\section{ZOZNAM LITERATÚRY}

[1] ANDRAŠKO, J. a kol. Zákon o kybernetickej bezpečnosti. Komentár. Bratislava: Wolters Kluwer SR s.r.o. 2018, s. 544 s.

[2] ANDRAŠKO, J., MESARČÍK, M.: Problematika GDPR v kontexte nariadenia eIDAS. In Digitalizácia, zmeny vonkajšieho prostredia a spoločnost’ budúcnosti. Bratislava, Právnická fakulta UK, 2018, s. 8-21.

[3] BAYUK, L. a kol.: Cyber security policy guidebook. Wiley, 2012, $270 \mathrm{~s}$.

[4] BERTHOTY, Jakub a kol. : V̌̌eobecné nariadenie na ochranu údajov. 1. vydanie. Praha : C.H. Beck, 2018.

[5] HAMELINK, C. J. The ethics of cyberspace. Sage, 2001, $224 \mathrm{~s}$.

[6] KOLOUCH, J., BAŠTA, P. a kol. CyberSecurity. Praha: CZ.NIC, z.s.p.o, 2019. 556 s.

[7] OLEJÁR, Daniel a kol.: Manažment informačnej bezpečnosti a základy PKI. Bratislava, 2015, $175 \mathrm{~s}$.

[8] OLEJÁR, Daniel a kol.: Informačná bezpečnost'. Bratislava, 2013. $246 \mathrm{~s}$.

[9] POLČÁK, R. Informace a data v právu. Revue pro právo a technologie 7, 2016, s. 67-91.

[10] POLČÁK, R. a kol. Právo informačních technológií. Praha: Wolters Kluwer ČR, 2018, s 656 s.

[11] POLČÁK, R. Kybernetická bezpečnost jako aktuální fenomén českého práva. Revue pro právo a technologie, 2015,č. 11, s. 95-149. [on-line]. Dostupné z: https://journals.muni.cz/revue/article/view/2980.

[12] POŽÁR, J. Informační bezpečnost. Plzeň: Vydavatelství a nakladatelství Aleš Čeněk, 2005, 309 s.

[13] TODOROV, D. Mechanics of Users Identification and Authentication. Fundamentals of Identity Management. USA: Auerbach Publications, 2007, 756 s. ISBN 978-1-4200-5219-0

[14] VAN DER HOF, Simone a kol.: Framing Citizen's Identities: The construction of personal identities in new modes of government in the Netherlands. Nijmegen: Wolf Legal Publishers, 2010, 258 s.

[15] VON SOLMS, R. a VAN NIEKERK, J. From information security to cyber security. In Computers \& Security, 2013, roč. 38, s. 97-102 
[16] WHITMAN, M, E. a MATTORD, H, J.: Principles of Information security. Boston: Course Technology, 2012, $617 \mathrm{~s}$.

[17] WONG, H. Cyber Security: Law and Guidance. Bloomsbury Professional, 2018, $792 \mathrm{~s}$.

[18] nariadenie Európskeho parlamentu a Rady (EÚ) 2016/679 z 27. apríla 2016 o ochrane fyzických osôb pri spracúvaní osobných údajov a o vol’nom pohybe takýchto údajov, ktorým sa zrušuje smernica 95/46/ES (všeobecné nariadenie o ochrane údajov)

[19] smernica Európskeho parlamentu a Rady (EÚ) 2016/1148 zo 6. júla 2016 o opatreniach na zabezpečenie vysokej spoločnej úrovne bezpečnosti sietí a informačných systémov v Únii

[20] zákon č. 275/2006 Z. z. o informačných systémoch verejnej správy a o zmene a doplnení niektorých zákonov

[21] zákon č. 305/2013 o elektronickej podobe výkonu pôsobnosti orgánov verejnej moci a o zmene a doplnení niektorých zákonov (zákon o e-Governmente)

[22] zákon č. 95/2019 Z. z. o informačných technológiách vo verejnej správe a o zmene a doplnení niektorých zákonov

[23] zákon č. 69/2018 Z. z. o kybernetickej bezpečnosti a o zmene a doplnení niektorých zákonov

[24] vyhláška NBÚ č. 164/2018 z. Z., ktorou sa určujú identifikačné kritériá prevádzkovanej služby (kritériá základnej služby).

[25] vyhláška NBÚ č. 165/2018 Z. z. ktorou sa určujú identifikačné kritériá pre jednotlivé kategórie závažných kybernetických bezpečnostných incidentov a podrobnosti hlásenia kybernetických bezpečnostných incidentov

[26] vyhláška NBÚ č. 362/2018 Z. z. ktorou sa ustanovuje obsah bezpečnostných opatrení, obsah a štruktúra bezpečnostnej dokumentácie a rozsah všeobecných bezpečnostných opatrení

[27] ISO/IEC 27001:2013 INFORMATION TECHNOLOGY -- SECURITY TECHNIQUES -- INFORMATION SECURITY MANAGEMENT SYSTEMS REQUIREMENTS

[28] ISO/IEC 27002:2013 INFORMATION TECHNOLOGY -- SECURITY TECHNIQUES -- CODE OF PRACTICE FOR INFORMATION SECURITY CONTROLS

[29] ISO/IEC 27032:2012 Information technology -- Security techniques -- Guidelines for cybersecurity 
[30] ISO/IEC 27000:2016 Overview and vocabulary

Toto dílo lze užít v souladu s licenčními podmínkami Creative Commons BY-SA 4.0 International (http://creativecommons.org/licenses/by-sa/4.0/legalcode). 